\title{
The Man of the Shroud of Turin: Is He Dead or Alive?
}

\author{
BERNARDO HONTANILLA CALATAYUD \\ Clínica Universidad de Navarra. Faculty of Medicine. University of Navarra \\ bhontanill@unav.es
}

ORCID: 0000-0001-6186-4791

\begin{abstract}
It has been assumed that the person represented on the Shroud of Turin is dead and the image corresponds to a person dead from crucifixion. We have conducted an analysis of the cadaveric data of a body and the presence of face life signs and we could think that the image could correspond to a living person. Therefore, it might correspond to a man starting a getting up gesture. If we examine the Gospels, a remarkable symmetry is found between the data obtained from the image and the events described in the Gospels, regarding the death and resurrection of Jesus.
\end{abstract}

Keywords: Shroud of Turin, Nasolabial folds, signs of life.

\section{Introduction}

The postural analysis of the figure present in the Shroud of Turin has been an object of study in recent decades. The majority of these analyses has been carried out by forensics who have described the appearance of the figure as reflecting the postmortem rigidity posture of a dead body after death by crucifixion (Bucklin 1982). It has been assumed that the figure corresponds to a person who has been crucified and has suffered the same injuries as those described in the Gospels (Bucklin 1982; Barbet 
1953; Meacham 1983) and that therefore the probability that it is the figure of Jesus is very high (Fanti and Marinelli 2005).

The present study is not aimed at identifying the person whose image appears in the Shroud, something that will be on hold until the DNA present in the Shroud, actually very deteriorated (Fanti and marinelli 2005) can be contrasted. We do not intend either to address whether the image was naturally or artificially produced, that is, whether it "emanated" from the body itself or was produced by external intervention. The aim of this study is to analyze through medical reasoning and based on the bibliographical sources available, whether the image on the Shroud is that of or represents a dead or a live human body and verify if there are contradictions between what we see in the Shroud and what we read in the Gospels.

To do this, we will assume, as most previous studies have done, that the image corresponds to Jesus of Nazareth, a Jewish prophet who lived in the first century, was killed by crucifixion around year 30 A.D., and was wrapped in the Shroud after his death. This assumption will enable us to apply up-to-date scientific medical knowledge and medical reasoning to the data obtained from the bibliographical sources regarding i.e., the previous nutritional/physiological state of the person before death, trauma and efforts prior to crucifixion, the posture of the body after death and potential manipulations to the corpse or the interval between torture and death, to give some examples. All these factors might affect the condition of the corpse and therefore, without knowing about them, it would be very difficult to analyze the anatomical features and body disposition of the image of the Shroud.

\section{Material and Methods}

The material of the study is based on the extensive collection of photopgraps taken during the STURP (Shroud of Turin Research Corporation) analysis performed in 1978. All of this material is open access to the public. However, having the printed figure as the only data, we cannot demonstrate that the image corresponds to Jesus of Nazareth or that 
he was actually crucified as we are unable to observe the piercing path of the nails in the hand and feet nor the path of the wound into the thorax. Moreover, the blood stains at the theoretical exit points from the dorsum of the hands and feet may correspond to superficial wounds at those points to simulate a crucifixion.

The reference material regarding the death of Jesus of Nazareth is made up of a body of literature and not a physical body or its remains. In this sense, the credibility of any study about the death of Jesus will be basically determined by the credibility of the sources. Reference material includes the writings of ancient Christians as well as non-Christian authors. Using the historical-legal method of scientific research, scholars have established the reliability and precision of the ancient manuscripts.

The most extensive and detailed descriptions of the life and death of Jesus are to be found in the Gospels of Matthew, Mark, Luke, and John. The other twenty-three New Testament books support but do not enlarge the detailed gospel records. The Gospels of Peter and Nicodemus also make references to the death of Jesus. Some contemporary Christian, Jewish, and Roman authors provide additional information on the 1st century Jewish and Roman legal systems as well as details on flogging and crucifixion. Seneca, Livy, Plutarco and others refer to the practices of crucifixion in their works. Jesus is mentioned by the Roman historians Cornelius Tacitus, Pliny the Minor, and Suetonius, by the non-Roman historians Thallus and Phlegon, by the satyr Lucian of Samosata, by the Jewish Talmud, and by the Jewish historian Flavius Josephus, despite the fact that the authenticity of certain works of the latter are questionable.

In order to analyze specific facial features we have carried out a study in the Faculty of Medicine at our university in which we examined the faces of the cadavers that were received as a donation for the Anatomy Department, together with photograps of people alive and compared just after death $(n=56)$. Special attention is focused to their nasolabial folds and the positioning of the lower lip. All cadavers were examined upon arrival, between 24-30 hours postmortem. Then, we established a comparison with their premortem appearance as observed in both the ID and their photograph showed by the family. Lapse of time between the photograph 
and death is less than one year. Three independent observers examined the presence or absence of nasolabial folds and the location of upper and lower lips.

\subsection{Description}

What can we infer about Jesus's phenotype and nutritional state from the historical texts? Jesus was a person who must have walked frequently. It has been described on many occasions that he moved from one region of Israel to another. There is no reason to believe that he was a pyknic or obese person as he did not have access to food on a regular basis and it has been recorded that he fasted frequently. Therefore, his hepatic glycogen reserve would frequently be depleted, as opposed to his muscular glycogen reserve that would be his main source of energy, which takes a few hours to disappear after fasting and intense exercise (Koolman 2003). Approaching the time of his death which took place on a Friday, we are told that the previous night he had eaten unleavened bread and wine, as well as the rest of traditional food eaten at the Séder Pésaj dinner such as lamb, boiled egg and bitter herbs, and even that several toasts were made (Matthew 26:26).

Therefore, Jesus, once he had physiologically overcome this fear and tension accompanied by bleeding, was led prisoner by a cohort to the presence of a high priest (John 18:13-24), where he received a blow to the face (John 18:22). Then, after Governor's trial, he was flogged (Mt 27:26). In the Shroud of Turin there are traces of between 100 and 120 blows, probably by means of an object called Flagellum Taxigatum, which consists of leather strings with three iron balls added at their distal end, as was the Roman custom. The Jews could only hit up to thirty-nine plus one lashes according to their law (William 1986) so we can assume that this was the Romans' doing. A body that receives such a large number of blows undergoes trauma with significant blood loss. A 1.3 litre blood loss has been calculated, taking into account the body surface of a man approximately 1.85 meters tall (Palacios-Carvajal 2017). This bilateral and alternating beating could have caused a traumatic shock. 
Once the flogging was over, a crown of thorns was placed on his head, which to some extent caused further bleeding and especially pain (Mt 27:29). Next, it is described that he had to carry a cross. It has been estimated that the patipulum weighed about $50 \mathrm{~kg}$, which he had to carry a certain distance and it is recounted that he fell several times, requiring the help of another person (Luke 23, 26).

\subsection{Crucifixion}

When he arrived at the place of crucifixion, he was nailed to the cross that he was carrying by means of nails in his hands and feet. It seems that there were two nails, one per foot, as was the Roman custom of crucifying and as is attested by numerous authors who described the appearance of crucified bodies as riding on horseback with the knees bent (Fernandez-Carvajal 1997). The sedile or supedanium located under the soles of the feet was arranged so that the crucified had some support and would thus be able to stand up and stretch the joints or take some air, according to some authors, for the sake of prolonging the torture for many hours. It has been described that the crucified person dies of suffocation (Barbet 1953) but such claims have been contradicted by other experiments in which several volunteers were hung on a cross and there was no visual evidence of breathing difficulties throughout the suspension. Subjectively, all volunteers affirmed that they had absolutely no trouble breathing during inspiration or expiration. A common complaint was a feeling of chest rigidity and leg cramps between 10 and 20 minutes into suspension. When this occurred, they were allowed to straighten their legs or come down. The spine of the volunteers never touched the cross except in the shoulder region where the contact was slight. Pain in the shoulders caused many of them to arch their bodies back so that the top of the head touched the stipes, thereby relieving some of the pain (Zugibe 1995).

We know that Jesus was alive while nailed to the cross from the sixth hour to the ninth hour (about 3 hours) and that he even spoke seven times, one of them with a cry just before dying. The fact that he spoke on so many occasions, and even cried out just before dying, despite the supposed respiratory distress suggests that there may not have been a venti- 
lation problem. There are some authors who note that he had a dislocated shoulder so that the movement of raising and lowering them to breathe would have been done only on one of them. This conclusion is reached by analysing the direction of the bleeding present on one of the forearms of the figure of the Shroud of Turin (Fanti and Marinelli 2005).

Let us now focus on his hands. Where did the nails penetrate? Some doctors claim that it was through the space of Destot (Barbet 1953). This space is located on the palm of the hand close to the little finger and would rarely cause paralysis of the median nerve. It has also been described that it could have been between the ulna and radius bones at the distal forearm, but the injury of the theoretical exit hole in the Shroud does not match with that site. Frederick Zugibe suggests that it was in the highest part of the palm and in an oblique direction upwards. In this way, a median nerve injury occurs, the skin of the hand is not torn at that site by the weight of the body and no bone is broken, with the nail exiting on the dorsum (Zugibe 1995). The author believes that Zugive's opinion provides the most logical explanation for a distal injury of the median nerve. A distal injury to the median nerve causes the thumb to extend and be placed in the same plane as the other four fingers and approximated to the index, this is called "the ape hand". It is produced by the action of various muscles: on the one hand, the long and short extensors of the thumb, innervated by the radial nerve, which cause the thumb to lie flat and, on the other hand, the adductor of the thumb, innervated by the ulnar nerve, which causes the thumb to approach the index. This is also facilitated by the paralysis of the opposing muscle of the thumb, as it is innervated by the median nerve. It is not possible to see the atrophy of the thenar eminence since that sign only occurs when muscle atrophy has been reached over time. However, the absence of visualization of the thumbs in the Shroud of Turin has been attributed to the paralysis of the median nerve (William et al 1986), a fact that is not possible because there is precisely a paralysis of the opposing thumb muscle, as it has previously been explained. Paintings or representations of the hand of Jesus crucified with the fingers in the form of a preacher or a benediction are not possible in a distal injury to the median nerve. The "benediction hand" only occurs 
when the median nerve injury is at the level of the elbow or more cranial (Torne 2017).

Continuing with the description of Jesus crucified we observe that for about three hours he stayed alive. The pain in the spine, arms and legs described in simulations of people in the crucifixion posture causes the subject to make a significant effort with the legs to rise and in order to rise, plantar support is needed. The friction of the nails against the median nerve with the raising and lowering movements of the body could trigger a painful click.

\subsection{Death}

After about three hours of crucifixion, Jesus died. "And bowing his head, he gave up his spirit" (John 19:30). The bowing of his head excludes the possibility of a death in tetanic contraction that could justify a posteriori or explain rigid body postures in any part of the body, especially in the face (Hontanilla 2020).

In summary, at the time of death, Jesus had been fasting for approximately twelve hours, exhausted, without reserves of liver glycogen, but probably without muscle glycogen depletion due to physical exertion because of the shortness of the agony, dehydrated, bled out, hypovolemic and with fever, in conditions of outdoor temperature more or less warm.

When a person dies, there is initially a general muscular relaxation and after approximately three hours postmortem stiffness begins, although this interval might fluctuate depending on muscle mass and other factors (Madea 2006; Martins et al 2015). Subjects who pass from life to death with instantaneous rigidity are rarely described, occurring only in death from cholera or in some electrocutions (Villalain 2010), and in reality they are practically non-existent (Madea 2006). The time until the stiffness is established is directly proportional to the amount of glycogen. Therefore, if the glycogen stores were depleted in Jesus, this rigidity would appear at an early stage (Madea 2006). The intensity of stiffness depends on many internal and external factors. Intense fatigue (in agonizing and prolonged deaths) and large hemorrhages decrease tissue hydration so that stiffness appears at an early stage, and is weak and of 
short duration (Villalain 2010). The whole of the passion comprises a progressive dehydration of the body, with nakedness facilitating the evaporation of sweat. This dehydration would have been asymmetric due to gravity and the vertical posture on the Cross, with a more intense dehydration in the arms than in the legs. However, muscular subjects make stiffness more intense. In the case of Jesus, the effort must have been very similar in the arms and legs to produce the lifting movements of the body. Temperature also has an influence on postmortem stiffness so that the hotter it is outdoors, the less intense it will be (Fisher and Fisher 2012). In summary, it is very difficult to determine the intensity of the rigidity that the body of Jesus could have presented since some data indicate that it could have been intense while other data denote that it could have been weak. Nevertheless, there is common agreement that it was early, so the onset would have been approximately 20-45 minutes after death due to the body's low glycogen reserve (Villalaín 2010; Bevilacqua 2018).

As described on several occasions in the literature, we must bear in mind that if we are to follow the Gospel's account, Jesus was dead on the cross for an hour or more. He died before his companions. In fact, he did not have his legs fractured as they did with the other two because it was getting late and Saturday was approaching (John 19:32). He was dead and the two companions alive, so we can conclude that he was dead for a longer period of time than the others. Eventually, because Saturday was approaching, the death of the companions was accelerated. Afterwards, his followers had to beseech Pilate to let them take away the body, so first they had to go before Pilate and then return to Golgotha. Consequently, it is reasonable to think that Jesus hung dead between the None hour ( $3 \mathrm{pm})$ and before the start of the first vigil ( $6 \mathrm{pm})$ on Saturday: between one and three hours, since he had to be taken down and buried before Saturday (Hontanilla 2020).

What could have happened to the body once it died? As previously explained, there would have been an initial relaxation of the entire musculature. In the Gospel it is recounted that "bowing his head, he gave himself in spirit" (John 19:30). This indicates that the neck muscles relaxed causing the head to drop. The head would have dropped at the level of 
the shoulder blades, as has been described (Maner 2008). The verticality of the cross would cause the jaw to drop and the mouth to open. The entire trunk would descend and cause a marked accentuation of knee flexion. This body descent would also cause a radial or upward rotation of the hands whose axis of rotation is the nail that supports them. This rotation would probably keep the extension of the thumb, placed flat and in line with the other four fingers, and it would not fall towards the palm of the hand by gravity (Figure 1).

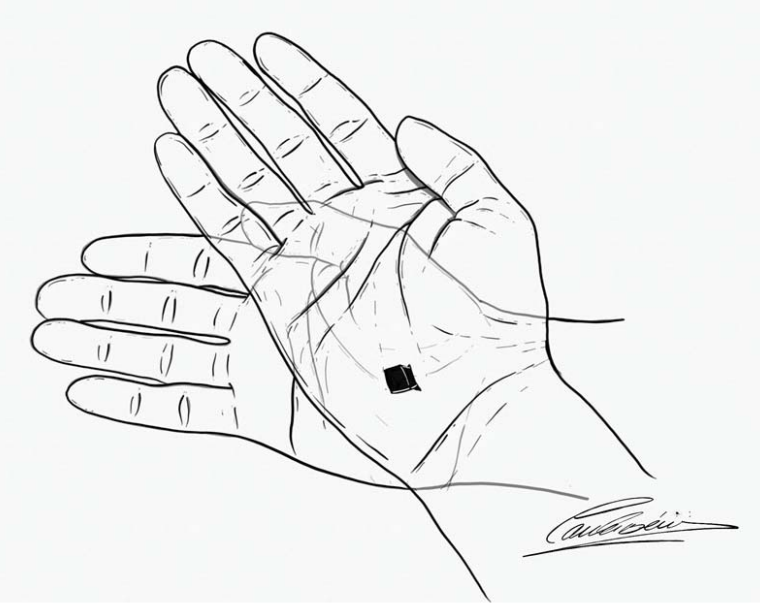

Figure 1. Upward rotation of the hand as the body descends after death. Note how the thumb remains at the same plane as the other four fingers, as occurs in a distal median nerve injury.

\subsection{Descent}

After a short time, the body would become rigid, fixing this relaxation posture with more or less intensity. Does the rigidity of this position matter to interpret the image that appears in the Shroud of Turin? I think not. The fundamental reason is that, once the body of Jesus had been lowered from the cross, the body was handled by the lifters, probably affected by his mother's embrace, by carrying and later by the gravediggers. Proof of this is that the arms, which should be open or separated from the body 
by the crucifixion, are placed downwards, as they appear in the Shroud. In the author opinion, it seems implausible that only the arms would have been manipulated and the mouth would not have been closed to correct the dropping of the jaw; and even the flexed legs or the semi-flexion of the trunk would have been rectified before burial. Therefore, the deduction that the image on the Shroud of Turin is caused by the last position of a rigid crucified corpse is a statement not really tenable. If this affirmation were accepted, we would have to assume that the corpse was absolutely rigid, stony, like a statue. One could think that this situation resembles that of a stressed animal about to get hunted. Once shot dead the animal becomes rigid after approximately 15 minutes. However, this phenomenon described in animals is not necessarily applicable to humans (Villalaín 2010). And even then, the Shroud's position would not coincide with that of a corpse with bent knees and with its head very low, as in a crucified body. Furthermore, there is no scientific data to support this assertion of stony rigidity in the case of Jesus (Hontanilla 2020).

Arguments justifying the idea that the intensity of the stiffness was almost stony and that in order to rectify the shoulder joints, the glenohumeral joints must have been dislocated or torn, can be regarded as speculative and their only motivation is to justify the posture of the corpse whose image is found in the Shroud of Turin. In adition, the posture does not reflect that of a crucified man. Moreover, we must bear in mind that we do not have any other case study of someone who has suffered anything similar to Jesus with at least three types of shock (traumatic, hypovolemic and cardiogenic) that would allow us to analyze the stiffness of the corpse and thus establish symmetries with the stiffness that could be present in the corpse of Jesus.

\section{Results}

It is known that we can place a corpse in postures that can simulate that they are alive and, conversely, we can make a live body adopt postures that simulate a corpse. In order to discern whether a body is dead or not, we must check for its breathing, pulse, pupillary dilation and neurological 
reflexes (Madea 2006; Shivpoojan 2018). All these signs are impossible to determine just by looking at the image in the Shroud of Turin for obvious reasons. We can intuit that he was dead because we assume that it was Jesus, we can see a wound in his side and we read in the Gospels that he died, but if we did not know these data it would be impossible to know if he was really dead. In reality, we neither see the path of the lance into the thorax nor see the path of the wounds on the hands or feet. Therefore, the question we must ask ourselves is the following: Is there any sign present in the Shroud figure whose presence is incompatible in a corpse or whose manipulation or simulation is impossible?

\subsection{Face}

Let us take a look at the bilateral nasogenian grooves that appear in the Shroud. They appear asymmetrical and is especially visible in the right side. The nasogenian and nasolabial folds are creases that appear bilaterally due to the traction of certain facial muscles (Barton and Gymesi 1997). This fold is formed when the muscles pull the upper lip in an upward and oblique direction preventing the skin from the cheek and its fat compartment, with its more elastic content, from hanging down onto the skin of the upper lip as age increases (Figure 2. left). These creases, depending on the phenotype of the person, usually appear from the age of 25 , especially in a static situation. They always appear when smiling. The older and thinner the person is, the more marked the folds will be.

They disappear when there is facial paralysis on the affected side (Figure 2 right). When there is bilateral facial paralysis, the two folds disappear. A situation of bilateral facial paralysis appears after death when the tractor muscles relax (Hontanilla 2020). Some interesting studies have shown that drooping of nasolabial folds is a sign of impending death due to relaxed tone of the facial muscles (Hui et al 2015). Moreover, multiple studies have demonstrated that changes in nasolabial folds are a physical sign that can be assessed with good interrater reliability (Buchner et al 2010). However, it is important to distinguish between an absence of the nasiolabial fold, which implies hanging of the cuataneous and fat tissue over the sulcus, and the presence of a depression due to the transition of 
cutaneous tissue over the cheek through the prominence of the maxillary bone in a cadaver (Figure 2 botton left and right).
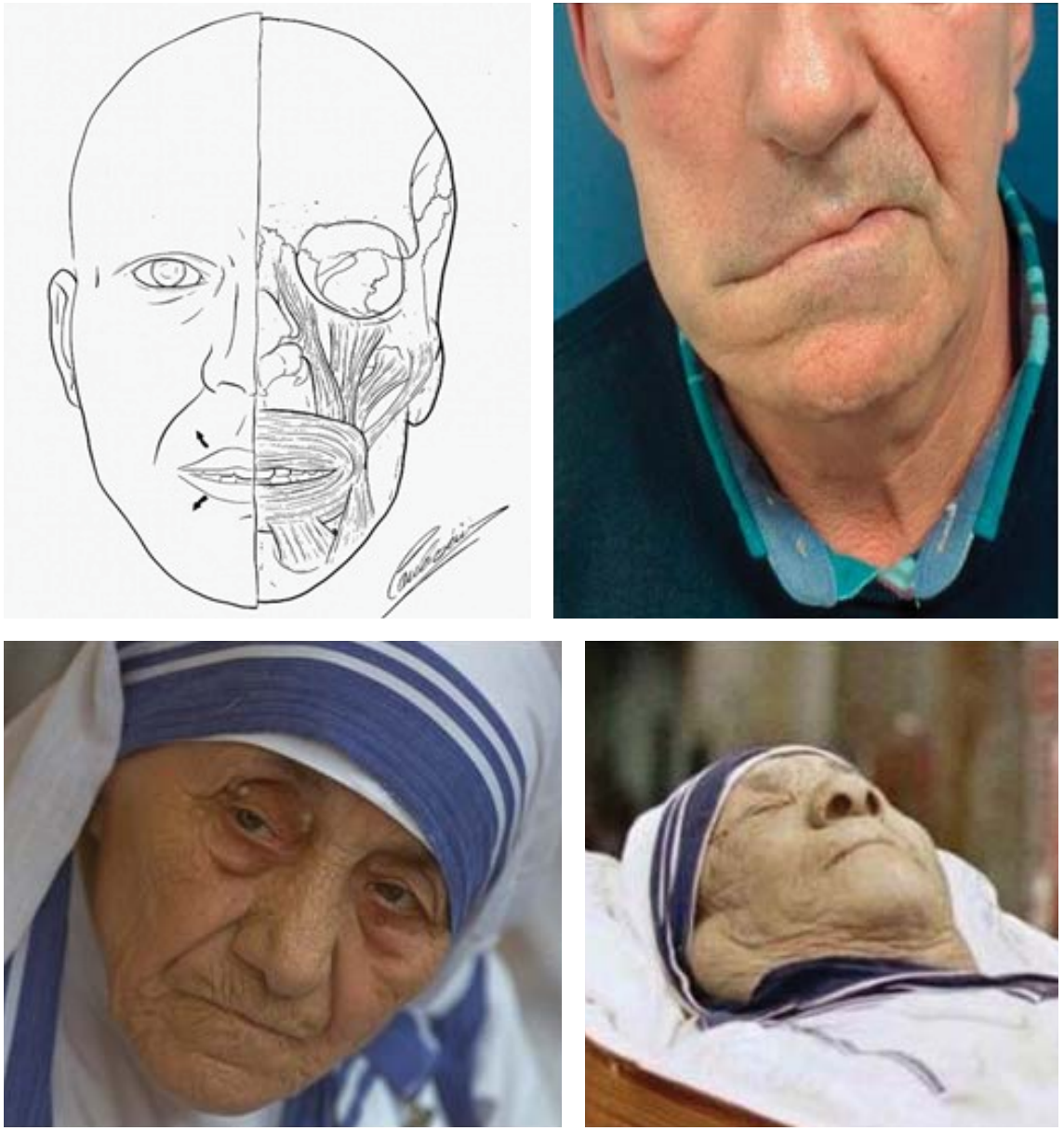

Figure 2. (Left) Schematic drawing showing the formation of the nasogenian and nasolabial folds due to the activity of the major and minor zygomatic muscles and the elevation of the upper lip and angle of the mouth. The descent of the lower lip is provoked by the depressor angulii oris and depressor labii inferioris (Right) Patient with facial paralysis. Note the deletion of the fold on the right side of the paralysis. Bottom right Mother Theresa of calcuta alive and left Mother Theresa after death. 
As previously explained, in a recent corpse the musculature relaxes and therefore the facial musculature relaxes (Wilkinson and Rynn 2012), the folds disappear (or flatten enormously in people with very deep grooves), the lower lip descends (this descent would be more pronounced if death has occured in an upright position) and the mouth is open. This is the initial moment of postmortem flaccidity. The presence of these creases on the face printed in the Shroud (Figure 3), especially in the right side, initially leads us to think that the person in the Shroud is either alive or his appearance could be justified by a phenomenon of postmortem rigidity.
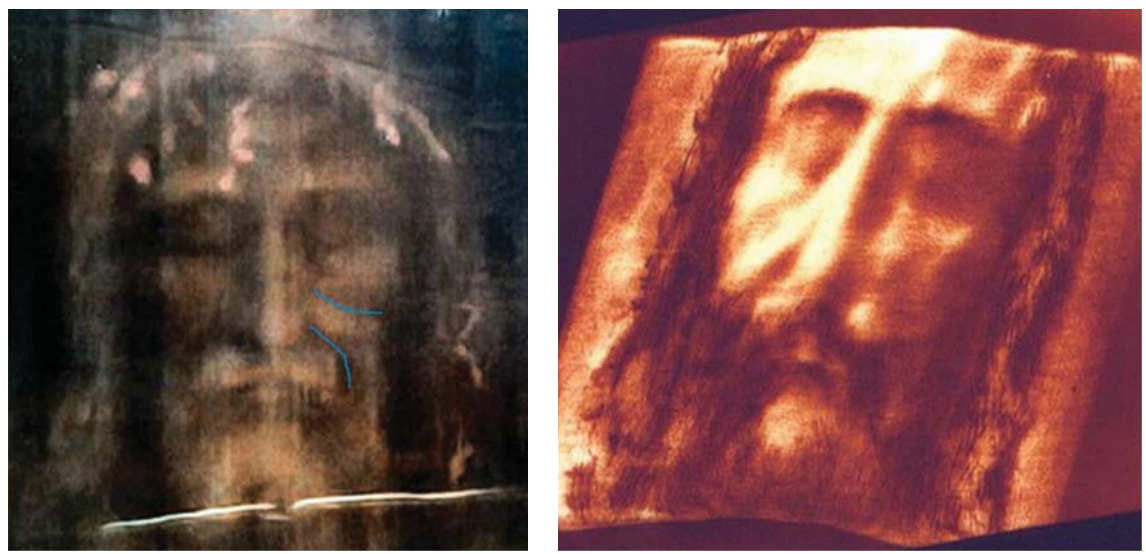

Figure 3. (left) Photographic negative of the face of the Shroud of Turin. Note the presence of marked nasolabial folds as well as a second crease superior and parallel to the right nasolabial fold (blue lines). (right) 3D image from the VP8 scan of the Shroud of Turin, clearly showing the presence of the nasolabial folds and the right upper sulcus. Images taken from https://www.shroud.com/meacham2.htm.

Now we are going to analyze the latter option as the most credible. First of all, there are no corpses that during the postmortem flaccid period sharpen the nasogenian folds, let alone when the position of the face is in a vertical situation with the upper and lower lips falling due to gravity, as occurs in a crucified person. If postmortem stiffness were the cause of the accentuation of the folds then the tractive muscles of the upper lip could cause the crease, but then the muscles that pull the lower lip in 
the opposite direction would lower it causing dental exposure so the lips would not appear closed as they do on the Shroud's face. We have carried out a study in the Faculty of Medicine at our university in which we examined the faces of the cadavers that were received as a donation for the Anatomy Department, with special attention to their nasolabial folds and the positioning of the lower lip. All cadavers were examined upon arrival, between 24-30 hours postmortem. Then, we established a comparison with their premortem appearance as observed in their ID photograph and the photographs showed by the family during the last year before death. Three independent observers concluded that all cadavers showed an absence of nasolabial folds, which were present in their premortem photograph, especially in athletic and leptosomic subjects. Moreover, the lower lip was found to be descended provoking an exposure of the upper teeth.

Furthermore, there is a second sulcus in the Shroud of Turin above the right nasolabial fold that is formed when the tone of the tractive facial muscles rises against an inflamed cheekbone. If the person were dead, the relaxation of the nasogenian and nasolabial folds would allow for a more homogeneous inflammation in the cheekbone compartment, so a generalized inflammation of the entire right cheek would be observed, in contrast to the left side, but without the formation of folds. The possibility of a facial spasm is excluded since he inclined his head. Furthermore, when a facial spasm occurs there is dental exposure, as previously explained. In the case at hand, the facial expression in the Shroud shows both marked nasolabial folds and closed lips. The asymmetrical appearance on the Shroud nasolabial folds seems that the Shroud could be tighten, wrapped around the body and therefore some traction could have been exerted and impress the Shroud on the two halves of the face differently. One could speculate that the Shroud was tighten from upper right aspect of the head to the lower left side. If it were the case then the nasal tip should be displaced to the left as the part of the nose is soft, but we observe the nasal tip centered in the image.

The next question we can ask ourselves is: can the formation of the nasogenian fold in a corpse be manipulated? The answer is yes, but it would involve a voluntary act on the part of the manipulator and it would 
take time to make a corpse look alive. Both the upper and lower lip would have to be raised, to cause the fold and to close against the upper lip respectively, for a period of time until the posture is fixed due to stiffness. This manipulation, although possible, seems absurd in the corpse of Jesus as it does not seem logical that the gravediggers at the time would think that there would be an image printed on the Shroud in which centuries later people would be able to observe that Jesus looked alive while being dead. What is more, when cleansing the face of the corpse (to prepare it for burial) the massaging movements would tend to flatten the nasogenian fold and not the other way around. Finally, we are astonished that some authors have stated that the Shroud's facial image is the typical Hippocratic face of a person about to die (Villalaín 2010). Any layman on the subject can compare the face on the Shroud and a Hippocratic face and see for himself the disparity between the two. Consequently, we think that the presence of the nasolabial folds could constitutes a sign of life in the image on the Shroud.

\section{Discussion}

Thus, if we assume the possibility that the person of the Shroud is alive, how to explain the disposition of the limbs in the Shroud? This posture may be due to a gesture of getting up. If we take a look at the 3D reconstruction of the 2D image on the Shroud, performed by the University of Padua, we can observe a man with a flexed neck, with the genitalia covered by his hands and an asymmetrical flexion of the knees, which is the typical posture of a man starting to get up without leaning against the floor with his hands (Figure 4). 

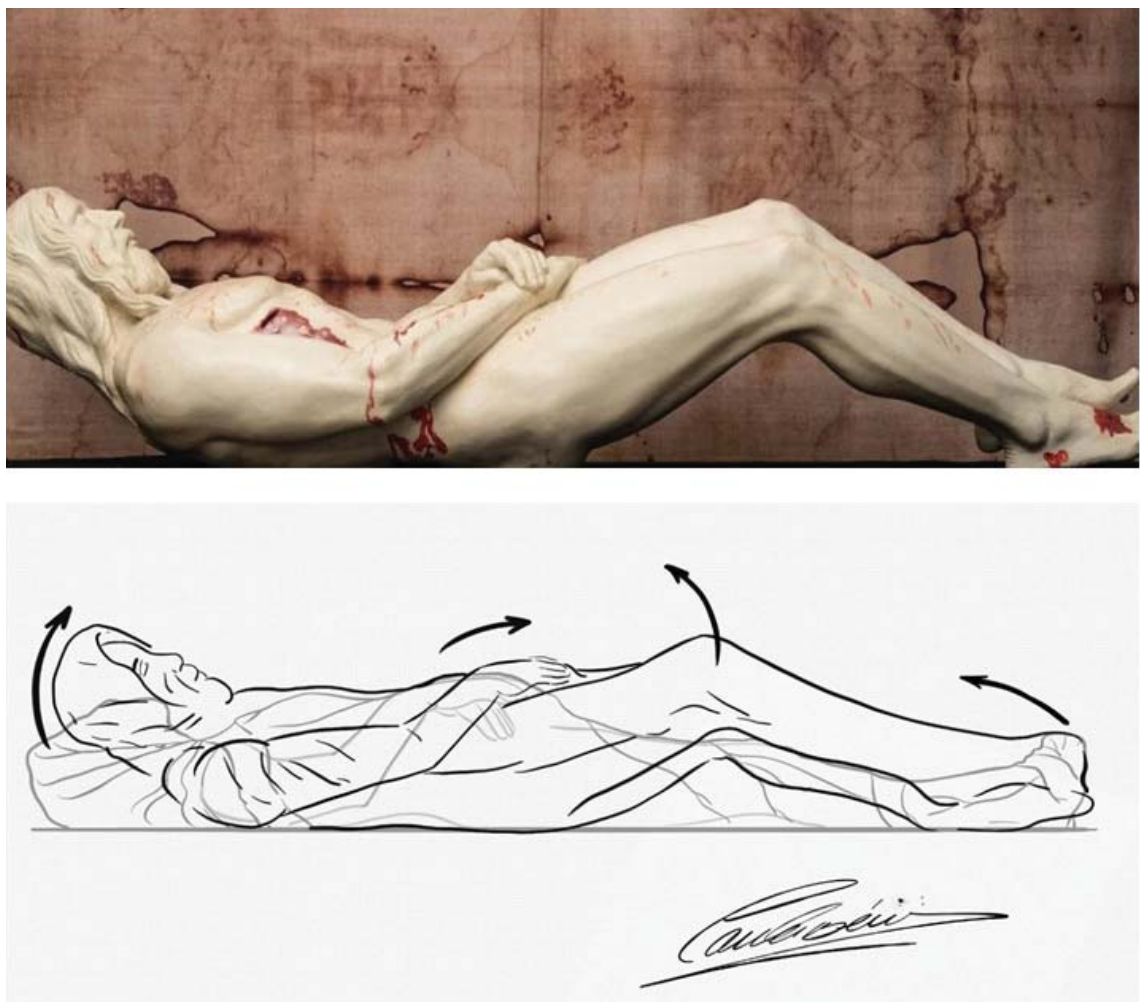

Figure 4. (Above) 3D reconstruction of the man according to the data extracted from the Shroud of Turin (taken from: https://ilbolive.unipd.it/ricostruito-corpo-impresso-sindone). (Below) Schematic drawing illustrating the initial movement of a man getting up.

Some authors stated that hands are able to reach and cover the genitalia because luxation of both glenohumeral joints have been provoked during the crucifixion or even by the gravedivers (Villalaín 2010). However, we have found people with the arms long enough that can reach and cover the genitalia in a complete horizontal position (figure 5). 


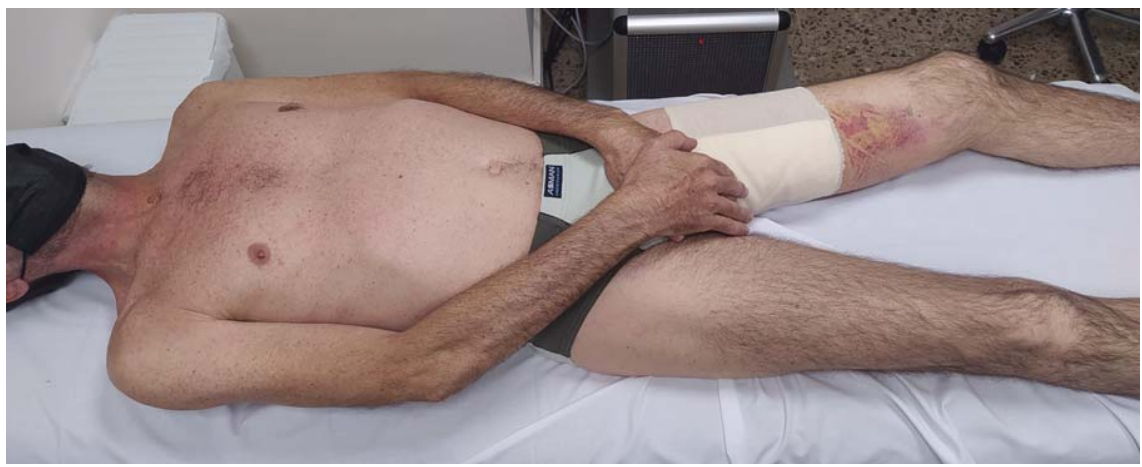

Figure 5. A 45 y.o man that covers his genitalia without any gesture of incorporation nor performing luxation of his shoulders. Note the length of his arms in respect to his body.

The thumbs which should be displayed in the Shroud due to the paralysis of the distal median nerve are in fact absent, which may be due to the person laying the left hand above the right hand and placing the thumb of the left hand ventrally surrounding the right wrist. Similarly, the thumb of the right hand is simply hidden behind the left hand. Therefore, it is reasonable to think that the absence of the thumbs in the Shroud can also be attributed to signs of life but not to the distal paralysis of the median nerve. Moreover, and further elaborating on this idea, the distal phalanges of the index, middle and ring fingers of the right hand are in semi-flexion compared to those on the left hand, which are in extension, a position hardly prepared by a gravedigger. Therefore, it is reasonable to conceive that during the maneuver of getting up, the hands are voluntarily covering the genitals.

It has been stated that the thorax of the figure of Turin is in forced contraction and with the hypogastrium contracted (Bucklin 1982). This posture has also been attributed to postmortem rigidity (Villalaín 2010), but may be indicating a getting up maneuver. Therefore, at the moment the image was produced, there was an inspiration and a contraction of the abdominal muscles, a situation that is contrary to the one immediately prior to death, as described: "But Jesus, again crying out in a loud voice, yealded up his spirit." (Matthew 27:50), which indicates that he expelled 
the air from the lungs. However, one of the problems that has been put forth is that if the person was breathing when the image was produced, this image would be blurred in the Shroud and yet a very sharp image is appreciated. We do not understand the reason for this statement. If the image was produced in an instant, like a flashlight, it is perfectly possible that it could have been produced at the moment of maximum inspiration when the movement had stopped. Nevertheless, the way in which the image was produced and the time it took to be produced remains a mystery. We must keep in mind that the variations in the intensity of the images in the Shroud correspond to the distance between the skin of the corpse and the cloth, as if it had been imprinted by some type of unknown "radiation" or "energy", so the greater the intensity of the negative the more proximity to the cloth. Thus, the image printed in the Shroud of the back of Jesus's body leaves an image of similar or less intensity than that of the front of the body, and yet there is no deformation of the image at the gluteal area or the back, that should exist if the corpse were resting against a hard surface. To give an explanation for this, it has been proposed that the 100 pounds of myrrh and aloes (about $40 \mathrm{kgs}$ ) that were used in the initial treatment of the body of Jesus (John 19:39) caused the figure not to be deformed, acting like a memory foam mattress (Llorente 2010). However, if we distribute about $40 \mathrm{kgs}$ of myrrh on a surface of $1.84 \times 1 \mathrm{~m}$, the thickness we achieve is only a few millimeters, which seems insufficient to justify the lack of gluteal or back deformation. We must keep in mind that the anti-decubitus mattresses used in hospitals have an approximate thickness of $15 \mathrm{~cm}$, which would entail a quantity of myrrh disproportionate to that used to make the foam effect.

So, how do we explain this lack of impression or veiling of the figure on the back of the body? One possibility would be that the body was levitating a few millimeters and, at that moment, initiated a getting up gesture with a forced inspiration, and then could have disappeared. The notion of the body of Jesus levitating while being alive after death should not pose a problem considering that his body no longer obeyed the laws of physics, as described in the Gospels when it is said to have crossed walls or appeared and disappeared (John 20:19-31). Moreover, Arquimedes' princi- 
ple did not affect his body when he walked over the sea of Galilee. Thus, it should not be strange that gravity could not affect his body when he came back to life after being dead. Another objection would be: If he is getting up, why do we see the left sole resting on the Shroud? Wouldn't it be strange to see a body rising with only the support of a single sole? Yes, certainly. But in reality the sole that we see corresponds to a blood stain. We are not actually seeing where the sole is located because its impression is not seen due to the alleged "radiation" but because of the blood stain.

Another problem would be the reason why the Shroud figure has his eyelids closed. It would have been easier to prove that he was alive if his eyelids were open. However, the fact of having the eyelids closed or open does not indicate whether someone is alive nor dead, since a corpse can also be left with the eyelids open and a living person can have them closed during sleep. If the author were artificial, it could be interpreted as an error in the execution of the work if what was intended was to capture the resurrection on the same object. If the author were natural, one reason should be that maintaining the eyelids closed should be more confortable especially when the Shroud is leaned against the eyelids.

The Shroud has two different stains coming from two different origins: one is the premortem and postmortem clots which means that a cadaver was present in the Shroud and the other somatic image of the Shroud caused by dehydration of the cellulose fibers of the cloth, that shows a living man. There is evidence to indicate that some of the blood deposits in the image precede the development of the image itself (Bucklin 1982). Therefore, this second stain is posterior to the clots as no dehydration of cellulose is present under the clots. Thus, both the premortem and postmortem blood that impregnate the Shroud could prove that the subject was alive and then died, and after dying the image appeared. Consequently, it is not possible that the body image printed in the Shroud, of a different nature, complementary and not superimposed on that of the blood clot stains, could come from a dead subject. Moreover, corpses do not provoke this type of stain on clothes. The blood stains show the signs of passion and death, which would have been produced when wrapping the shroud around the dead body of Jesus, and the body stain shows the 
figure of a man showing signs of life that I have presented throughout the article, which would have been produced in the hypothetic moment of Resurrection.

Is it really the body of the risen Jesus? It is the author's opinion that interpreting the image in the Shroud of Turin scientists are having a death bias. Just the opposite of what happened to Abraham Wold, a Jewish mathematician during the World War II, when he adviced the engineers to reinforce the non-damaged areas of the planes that made it back to the air bases. Everybody had decided to reinforce the areas where bullets had pierced the planes but they did not consider that the most serious impacts of bullets were those that provocked the planes to not make it back to the air bases so they did not have experience. This fact became known as the survival bias (https://limargas.com. Caso de Abraham Wald). The reason why science has been so reluctant to recognize a living person in the image of the Shroud and has always identified the image as a dead person might reside in an intelectual prejudice, our reason refuses to see what it can't understand and is bound to see what it expects to see. Scientists approach the Shroud expecting to see a dead body and that is all they can see, as science doesn't have experience of resurrecting bodies. This resembles the attitude of Mary Magdalene in the Gospel when she encounters Jesus resurrected but is unable to recognize him, because she approached the tomb expecting to find the dead body of Jesus. Science does not record the experience of a dead person coming back to life, and therefore it will never be able to follow that step, nor can it explain it.

There could also be a theological concern, which relates to the impossibility that a person who returned to life should interact with matter. Firstly, no one of us except those in the first century, has had the experience of seen a resurrected person to say if a resurrected body interacts with matter or not. However, if we follow the Gospels' accounts, we see that the risen Jesus ate and drank and warned that he was not a ghost. As recorded in the Gospels, Jesus with his risen body could interact with matter, cross it or move without impediment. The fact of resurrecting a body does not imply that it is completely spiritual or immaterial. It is a body, but with glorious characteristics that can interact with or 
traverse matter and move without impediment, as described in the Gospels (John 20:19-31). Finally, as previously explained, there is no contradiction between what is narrated in the Gospels (the passion, death and resurrection of Christ) and what can be observed in the Shroud (signs of punishment according to the Roman law and tradition, death on a cross and signs of life, in the same object) as Pope St. John Paul II stated "the Shroud of Turin is the mirror of the Gospel" (Speech of St. John Paul II. Cathedral of Turin. May 24 $4^{\text {th }}, 1998$ ). If the Shroud is the mirror of the Gospels then the passion, the death, and also the resurrection must be represented on it and, in effect, it is.

Now, it is mandatory to make the following reflection: how is it possible that we have inherited all the knowledge of the ancients regarding medicine, chemistry, physics, painting or art and yet there remains this important gap in our knowledge to explain how this extraordinary figure represented in the Shroud of Turin was made? From extensive analytical studies of the Shroud of Turin we know that the image is not man-made and from the forensic studies of the blood marks we know that a crucified man was laid out of his back and wrapped in this cloth. But the question still remains as to what caused the shroud image as corpses do not provoke this type of images. A forensic study of the blood marks and the analysis of the effect of gravity on surface anatomy suggest that even a natural event is not the most probable cause of the shroud image formation (Gilbert Lavoie 2010). Moreover, the same author suggests that the image could correspond to Christ at the moment of his Resurrection. It is a mystery that remains scientifically inexplicable and failure to answer this question leaves the intellect on hold. While science alone (face to face with the Shroud) can only admire an objet, science with faith move the heart to increase the love for a living God.

\section{Conclusion}

I can affirm that, whether the Shroud of Turin is true or a representation, what was intended to be shown in that same object is the passion, death and resurrection of Jesus as it is described in the Gospels. There- 
fore, there is no contradiction between what we see in the shroud (signs of death and life) and those described in the Gospel (death and resurrection of Christ).

\section{Aknowledgements}

I want to thank Dr. Miriam Vicente for her help in the preparation of the manuscript and for the commentaries and suggestions. I also want to thank to Dr. Rafael Texeira, Head of the Forensic and Legal Medicine Department at the Hospital de Navarra, Dr. Elisa Mengual, professor of anatomy at the Faculty of Medicine at the University of Navarra for allowing me to observe the cadavers at the Faculty of Medicine. I also thank professor Ruben Herce, José Fernández-Capo, professor José Manuel Giménez-Amaya and Dr. Cristina Aubá for their commentaries and suggestions. Finally, Dr. Carlos Berniz for the preparation of the drawings.

\section{Disclosure Statement}

No financial interest or benefit has arisen from the direct applications of this research.

\section{References}

Barbet, Pierre. 1953. A Doctor at Calvary: The Passion of Our Lord Jesus Christ As Described by a Surgeon. New York: P.J. Kenedy \& Sons.

Barton, Fritz E. and Gyimesi Ildiko M. 1997. "Anatomy of the nasolabial fold". Plastic and Reconstructive Surgery 10: 1276-1280.

Bevilacqua Matteo, Concheri, Gianmaria, Fanti Gulio and Rodella Sergio. 2018. "Rigor Mortis and News obtained by the Body's Scientific Reconstruction of the Turin Shroud Man". Journal of Forensic Science and Technology, https://doi. org/10.17352/pifst.000010.

Buchner, Lawrence, Vamvakias, George, and Rom, Dror. 2010. "Validation of a photonumeric wrinkle assessment scale for assessing nasolabial fold wrinkles”. Plastic and Reconstructive Surgery 126: 596-601. 
Bucklin, Robert. 1982. "The Shroud of Turin: viewpoint of a forensic pathologist”. Shroud Spectrum International 5: 3-10.

Fanti, Giulio and Marinelli, Emmanuella. 2005. "A probabilistic model to quantify the results of the research of the Turin Shroud". Third Dallas International Confrenece on the Shroud of Turin. Dallas, Texas. Sept. 8-11. https://www. shroud.com/.

Fernández-Carvajal, Francisco. 1997. La Vida de Jesús. Madri: Ediciones Palabra S.A.

Fisher, Barry A., and Fisher, David. R. 2012. Techniques of crime scene investigation. Ed. Taylor and Francis group. $8^{\text {th }}$ edition. Boca Ratón. Florida.

Hontanilla, Bernardo. 2020. “Signos de vida en la Síndone de Turín.” Sciencia et Fides. 8 (1): 9-30. DOI: http://dx.doi.org/10.12775/SetF.2020.001.

https://limargas.com/cuando-lo-obvio-no-es-cierto-el-caso-de-abraham-wald/ https://www.vatican.va/content/john-paul-ii/es/speeches/1998/may/documents/ hf_jp-ii_spe_19980524_sudario.html

Hui, David, Hess, Kenneth, Dos-Santos, Renata, Chisholm, Gary and Bruera, Eduardo. 2015. "A Diagnostic Model for Impending Death in Cancer Patients: Preliminary Report.” Cancer 121: 3914-3921.

Koolman, Jan., and Heinrich, Klua Rhom.R. 2003. Bioquímica. Texto y atlas. Madrid: Ed. Panamericana.

Lavoie, Gilbert. 2010. “Turin Shroud: A medical forensic study of its blood marks and image.” Proceedings of the International Workshop on the Scientific approach to Acheiropoietos Images. ENEA Frascaty, Italy, 4-6 may.

Llorente, Carlos. 2010. La primera semana santa de la historia. Madrid: Ediciones San Román.

Madea, Burkhard. 2006. The estimation of the time since death. The Student's HandBook of Forensic Medicine and Medical Police. Florida: Tylor and Francis group. Maner, Yves. 2008. "The history of Military Graves from Antiquity to the 19th century." http://www.cheminsdememoire-ordpasdecalais.fr/lhistoire/la-memoirede-la-grande-guerre/lhistoire-des-sepultures-militaires-de-lantiquite-au-xixesiecle.html.

Martins, Pedro, Ferreira, Francisca, Natal, Jorge, Renato, Parente, Marco, Santos, Agostinho. 2015. "Necromechanics: Death-induced changes in the mechanical properties of human tissues." Proceedings of the Institution of Mechanical Engineers, Part H. 229: 343-9. DOI: 10.1177/0954411915581409.

Meacham, William. 1983. "The authentication of the Turin Shroud: An issue in archaeological epistemology.” Current anthropology 24: 283-311. 
Palacios-Carvajal José. 2017. La Sábana Santa. Estudio de un cirujano. Madrid: Ed. Espejo de tinta.

Shivpoojan, Kori. 2018. "Time since death from rigor mortis: Forensic prospective." J Forensic Science \& Criminal Investigation 9, 1-10. DOI: 10.19080/JFSCI.2018.09.5557710010.

Torne, Charles. 2017. Grabb And Smith's Plastic Surgery. New York: Wolters Kluwer/ Lippinkott Williams and Wilkins.

Villalaín, José. 2010. “Estudio de la rigidez cadavérica que presenta la Síndone de Turín.” Cuadernos de Medicina Forense. 16: 109-123.

Wilkinson, Caroline and Rynn Chistopher 2012. "Post-mortem prediction of facial appearance.” In Craniofacial identification, edited by Caroline Wilkinson, Christopher Rynn, 166-83. New York: Cambridge University Press.

William, D., Edwards, Wesley, J. Gabel, M., Floyd, Hosmer. 1986. "On the Physical Death of Jesus Christ." JAMA The Journal of American Medical Association 255: $1455-1463$.

Zugibe, Frederick. 1995. Pierre Barbet Revisited. Reprinted from Sindon N. S., Quad. No. 8.

Zugibe's, Frederick Website: http://www.crucifixion-shroud.com/. 